\title{
THE CAUSE OF ARTERIAL HYPOXEMIA AT REST IN PATIENTS WITH “ALVEOLAR-CAPILLARY BLOCK SYNDROME”*
}

\author{
By T. N. FINLEY,† E. W. SWENSON ‡ AND J. H. COMROE, JR.
}

(From the Cardiovascular Research Institute, University of California School of Medicine, San Francisco)

(Submitted for publication July 24, 1961 ; accepted October 27, 1961)

Hypoxemia in patients with "alveolar-capillary block syndrome" is believed to be due to a barrier to the diffusion of oxygen caused by thickened alveolar and capillary membranes $(1,2)$. Theoretical considerations indicate that thickened membranes should not result in a $\mathrm{Po}_{2}$ difference between alveolar gas and pulmonary capillary blood when patients with impaired diffusion breathe 100 per cent $\mathrm{O}_{2}$. Inhalation of $\mathrm{O}_{2}$, therefore, should always correct hypoxemia in patients in whom a barrier to diffusion is the only defect. The reasoning is as follows: inhalation of $\mathrm{O}_{2}$ at sea level raises alveolar $\mathrm{Po}_{2}$ to about $670 \mathrm{~mm}$ $\mathrm{Hg}$, and the large initial $\mathrm{Po}_{2}$ difference between alveolar gas and blood entering the pulmonary capillaries (600 to $630 \mathrm{~mm} \mathrm{Hg}$ ) causes a rapid diffusion of $\mathrm{O}_{2}$ across even thickened alveolarcapillary membranes and prompt saturation of the hemoglobin $(3,4)$. After hemoglobin is saturated with $\mathrm{O}_{2}$, the $\mathrm{O}_{2}$ behaves like an inert gas and enters the blood only in physical solution and almost instantaneously, so that blood leaving the pulmonary capillaries is in equilibrium with the $\mathrm{Po}_{2}$ in the alveolar gas.

Our original plan was to test this theory by measuring directly the arterial $\mathrm{Po}_{2}$ of patients with "pure" alveolar-capillary block syndrome while they were breathing pure $\mathrm{O}_{2}$. If the theory is correct (and if pulmonary artery-to-vein shunts are not increased in these patients) the arterial $\mathrm{PO}_{2}$ should equal that of healthy subjects breathing pure $\mathrm{O}_{2}(620$ to $650 \mathrm{~mm} \mathrm{Hg})$. On analysis of our data we realized that the arterial hypoxemia in patients with alveolar-capillary block syndrome

\footnotetext{
* Supported in part by Grant H-4029 from the United States Public Health Service.

† Special Fellow, National Tuberculosis Association. Present address: Dept. of Anesthesiology, Univ. of Washington, Seattle, Wash.

‡ Senior Fellow, San Francisco Heart Association. Present address: Cardio-Pulmonary Lab., VA Hospital, Coral Gables, Fla.
}

was due to uneven ventilation-blood flow relationships and increased vein-to-artery shunts rather than to a barrier to diffusion of $\mathrm{O}_{2}$. This led us to conclude that pulmonary disease rarely alters alveolar-capillary membranes uniformly throughout the lung and, therefore, uneven ventilation-blood flow relationships must occur. Nonuniform distribution of gas and blood, we believe, represents an important cause of arterial hypoxemia in patients with "impaired diffusion."

\section{SUBJECTS AND METHODS}

We studied 11 patients with diseases in which the primary defect was alveolar-capillary block (Table I). The diagnosis was made on clinical grounds, X-ray and pulmonary function tests in all, by lung biopsy in four (E.S., J.R., O.B., P.S.), by lymph node biopsy in two (J.W., B.F.), and at autopsy in one (J.B.). The results of pulmonary function studies are shown in Table II. All the patients had slight to marked reduction in vital capacity and total lung capacity, normal or low arterial blood $\mathrm{PCO}_{2}$, normal 7-minute nitrogen washout (5), normal or elevated alveolar ventilation, decreased diffusing capacity as determined by the single-breath $\mathrm{CO}$ test (6), and maximal flow rates considerably in excess of those characteristic of obstructive pulmonary disease such as asthma or emphysema. Pulmonary compliance was measured in four; in all of these it was below normal.

Each patient was then studied by the technique described by Finley (7) for the determination of uneven ventilation-blood flow distribution in the lungs. Briefly, the technique consists of $a$ ) continuous measurement of arterial $\mathrm{Po}_{2}$ during nitrogen washout by a Clark $\mathrm{O}_{2}$ electrode inserted in a flow-through cuvet, and $b$ ) simultaneous measurement of $\mathrm{PN}_{2}$ and $\mathrm{PCO}_{2}$ in inspired and expired gas at the mouthpiece. From these measurements the (A-a) $\mathrm{Po}_{2}$ difference due to "absolute" shunt can be calculated (4), and curves can be drawn which describe the ventilation-blood flow relationship through well and poorly ventilated regions of the lungs. We calculated the mixed capillary $\mathrm{O}_{2}$ saturation during breathing of air, assuming that the distribution of ventilation and blood flow through the lungs was the same as that calculated during $\mathrm{O}_{2}$ breathing, and that the cardiac output remained the same. This calculation is similar to that made by Briscoe (8) for patients with emphysema. 
TABLE I

Clinical data

\begin{tabular}{|c|c|c|c|c|c|c|c|c|}
\hline \multicolumn{3}{|c|}{ Patient } & \multirow[b]{2}{*}{$\mathrm{Ht}$} & \multirow[b]{2}{*}{ Wt } & \multirow[b]{2}{*}{ BSA } & \multirow[b]{2}{*}{ Clin. diag.* } & \multirow[b]{2}{*}{$\mathrm{X}$-ray diagnosis } & \multirow[b]{2}{*}{ Pathol. diagnosis } \\
\hline & Sex & Age & & & & & & \\
\hline J.W. & $\sigma^{\top}$ & 44 & $\begin{array}{c}c m \\
158\end{array}$ & $\begin{array}{c}k g \\
65.0\end{array}$ & $\begin{array}{c}m^{2} \\
1.66\end{array}$ & PS & $\begin{array}{l}\text { Bilat. fibronod. } \\
\text { densities }\end{array}$ & $\begin{array}{l}\text { Noncaseating granuloma } \\
\text { (lymph node) }\end{array}$ \\
\hline F.F. & ○ & 44 & 162 & 52.6 & 1.55 & H-R syn. & $\begin{array}{l}\text { Diffuse bilat. } \\
\text { infiltrates }\end{array}$ & \\
\hline E.S. & ९ & 53 & 168 & 77.0 & 1.82 & PIF & $\begin{array}{l}\text { Diffuse nod. } \\
\text { infiltrates }\end{array}$ & $\begin{array}{l}\text { Patchy interstit. } \\
\text { fibrosis, atelectasis } \dagger\end{array}$ \\
\hline J.R. & $\sigma^{7}$ & 43 & 165 & 75.0 & 1.82 & H-R syn. & $\begin{array}{l}\text { Bilat. pulm. } \\
\text { fibrosis }\end{array}$ & Interstit. fibrosis $\dagger$ \\
\hline R.R. & $\sigma^{\pi}$ & 61 & 169 & 74.6 & 1.86 & PIF & $\begin{array}{l}\text { Diffuse nod. } \\
\text { changes }\end{array}$ & \\
\hline B.F. & \% & 23 & 167 & 50.8 & 1.55 & PS & $\begin{array}{l}\text { Diffuse patchy } \\
\text { infiltrates }\end{array}$ & $\begin{array}{l}\text { Noncaseating granuloma } \\
\text { (lymph node) }\end{array}$ \\
\hline H.S. & ㅇ & 35 & 164 & 58.2 & 1.63 & PIF & $\begin{array}{l}\text { Retic. densities } \\
\text { throughout }\end{array}$ & \\
\hline O.B. & $\%$ & 46 & 161 & 58.0 & 1.61 & PIF & $\begin{array}{l}\text { Diffuse nod. } \\
\text { densities }\end{array}$ & $\begin{array}{l}\text { Interstit. fibrosis, } \\
\text { inflammation } \dagger\end{array}$ \\
\hline P.S. & $\sigma^{\top}$ & 76 & 168 & 65.5 & 1.75 & PIF & Diffuse infiltrates & Interstit. fibrosis $\dagger$ \\
\hline A.W. & $\sigma^{7}$ & 70 & 168 & 79.2 & 1.89 & H-R syn. & $\begin{array}{l}\text { Extensive bilat. } \\
\text { infiltrates }\end{array}$ & \\
\hline J.B. & & 21 & 165 & 56.9 & 1.62 & CVD & $\begin{array}{l}\text { Bilat. patchy } \\
\text { infiltrates }\end{array}$ & $\begin{array}{l}\text { Extensive interstit. } \\
\text { fibrosis } \ddagger\end{array}$ \\
\hline
\end{tabular}

* PS = pulmonary sarcoidosis $; \mathrm{H}-\mathrm{R}$ syn. = Hamman-Rich syndrome; PIF = pulmonary interstitial fibrosis; CVD $=$ collagen vascular disease.

$\dagger$ Based on lung biopsy.

$\ddagger$ Based on postmortem examination.

The saturation drop due to shunts during inhalation of $\mathrm{O}_{2}$ was then subtracted to give the calculated arterial saturation. This final value represents the arterial saturation resulting only from unevenness of ventilation and perfusion and vein-to-artery shunts in the lung. In
Patients A.W. and J.B. this calculation was carried out only during the initial study and not late in the course of their illness (the calculation of unevenness of pulmonary blood flow in the presence of large pulmonary artery-to-vein shunts may be inaccurate).

TABLE II

Pulmonary function data *

\begin{tabular}{|c|c|c|c|c|c|c|c|c|c|c|c|}
\hline Patient & VC & TLC & $\mathrm{SBO}_{2}$ & $\begin{array}{l}7 \text {-min } \mathrm{N}_{2} \\
\text { washout }\end{array}$ & PDS/Vt & VA & $\mathrm{PaCO}_{2}$ & Dco & MEFR & MIFR & $\mathrm{CL}_{\mathrm{L}}$ \\
\hline & \multicolumn{2}{|c|}{$\%$ predict. } & $\Delta \% N_{2}$ & $\% \mathrm{~N}_{2}$ & $m l / m l$ & $L / \min$ & $m m H g$ & $\begin{array}{c}\% \text { pre- } \\
\text { dict. }\end{array}$ & $L / \min$ & $L / \min$ & $\begin{array}{c}L / c m \\
\mathrm{H}_{2} \mathrm{O}\end{array}$ \\
\hline J.W. & 74 & 73 & 4.0 & 1.0 & 0.34 & 6.8 & 32 & 58 & 136 & 333 & \\
\hline F.F. & 54 & 44 & 11.0 & 2.0 & 0.53 & 3.1 & 42 & 54 & 214 & 147 & 0.02 \\
\hline E.S. & 78 & 83 & 5.0 & 1.2 & 0.33 & 4.3 & 35 & 34 & 120 & 125 & \\
\hline J.R. & 70 & 80 & 2.5 & 2.2 & 0.42 & 5.7 & 40 & 23 & 375 & 250 & 0.06 \\
\hline R.R. & 99 & 75 & 3.5 & 1.4 & 0.50 & 4.3 & 30 & 49 & 330 & 273 & \\
\hline B.F. & 43 & 44 & 5.5 & 1.0 & 0.35 & 5.8 & 34 & 52 & 330 & 250 & \\
\hline H.S. & 71 & 68 & 2.5 & 0.9 & 0.41 & 4.4 & 32 & 58 & 107 & 136 & 0.07 \\
\hline O.B. & 50 & 57 & 5.5 & 1.7 & 0.41 & 3.7 & 36 & 53 & 188 & 150 & \\
\hline P.S. & 56 & 57 & 7.0 & 1.2 & & & 39 & 32 & 115 & 107 & 0.07 \\
\hline A.W. & 35 & 51 & 6.0 & 0.5 & 0.59 & 5.3 & 28 & 5 & 250 & 230 & \\
\hline J.B. & 93 & 93 & 1.7 & 0.9 & 0.25 & 4.6 & 34 & 74 & 300 & 250 & \\
\hline
\end{tabular}

$* \mathrm{VC}=$ vital capacity; TLC $=$ total lung capacity; $\mathrm{SBO}_{2}=$ rise in $\mathrm{N}_{2}$ concentration between 750 and $1,250 \mathrm{ml}$ expired after a single breath of pure $\mathrm{O}_{2} ; \mathrm{PDS}=$ physiological dead space; $\mathrm{VT}=$ tidal volume; $\dot{\mathrm{VA}}_{\mathrm{A}}=$ alveolar ventilation; $\mathrm{PaCO}_{2}=$ arterial $\mathrm{CO}_{2}$ tension; Dco $=$ breath-holding diffusing capacity for $\mathrm{CO}$ at rest; MEFR and MIFR = maximal expiratory and inspiratory flow rates; $\mathrm{CL}_{L}=$ lung compliance. 
TABLE III

Maximal arterial blood $\mathrm{O}_{2}$ tension $(\mathrm{mm} \mathrm{Hg})$ during inhalation of $\mathrm{O}_{2}{ }^{*}$

\begin{tabular}{lccccc}
\hline Patient & PB & PACO2 & $\mathrm{PAO}_{2}$ & $\mathrm{PaO}_{2}$ & $(\mathrm{~A}-\mathrm{a}) \mathrm{Po}_{2}$ \\
\hline J.W. & 744 & 32 & 661 & 563 & 98 \\
F.F. & 745 & 25 & 669 & 627 & 42 \\
E.S. & 747 & 30 & 666 & 644 & 22 \\
J.R. & 746 & 39 & 656 & 639 & 17 \\
R.R. & 750 & 34 & 665 & 660 & 5 \\
B.F. & 743 & 35 & 657 & 610 & 47 \\
H.S. & 745 & 26 & 668 & 585 & 83 \\
O.B. & 747 & 33 & 663 & 581 & 82 \\
P.S. & 742 & 29 & 662 & 598 & 64 \\
A.W. & 743 & 31 & 661 & 630 & 31 \\
& 743 & 23 & 669 & 262 & 407 \\
J.B. & 747 & 34 & 662 & 624 & 38 \\
& 745 & 60 & 634 & 40 & 594
\end{tabular}

${ }^{*} \mathrm{~PB}=$ barometric pressure; $\mathrm{PACO}_{\mathrm{A}}=$ alveolar $\mathrm{CO}_{2}$ tension; $\mathrm{PAO}_{2}=$ alveolar $\mathrm{O}_{2}$ tension; $\mathrm{PaO}_{2}=$ arterial $\mathrm{O}_{2}$ tension; (A-a) $\mathrm{Po}_{2}=$ alveolar-to-arterial $\mathrm{O}_{2}$ tension difference. Second values for A.W. and J.B. represent studies late in the disease. $\mathrm{PH}_{2} \mathrm{O}$ was assumed to be $47 \mathrm{~mm} \mathrm{Hg}$ in all cases; $\mathrm{PAO}_{\mathrm{O} 2}$ is calculated from measured $\mathrm{PB}_{\mathrm{B}}, \mathrm{P}_{\mathrm{A}_{\mathrm{N}} 2}(4$ $\mathrm{mm}$ in all cases), $\mathrm{PACO}_{2}$ and assumed $\mathrm{PH}_{2} \mathrm{O}$.

\section{RESULTS}

The highest arterial blood $\mathrm{Po}_{2}$ for each of these patients during the inhalation of $\mathrm{O}_{2}$ is shown in Table III. Compared with the arterial $\mathrm{Po}_{2}$ of normal subjects during pure $\mathrm{O}_{2}$ breathing (8), the (A-a) $\mathrm{PO}_{2}$ difference is within normal limits in Patients F.F., E.S., J.R., R.R., B.F., A.W., and J.B when studied initially (the second values for AW. and J.B. represent studies late in the course of their disease). This proves that the theoretical considerations are indeed correct; i.e., when the
$\mathrm{Po}_{2}$ is increased to high levels in the alveolar gas, there is no $(\mathrm{A}-\mathrm{a}) \mathrm{Po}_{2}$ difference except that due to normal venous admixture (pulmonary arteryto-vein shunts, bronchial and thebesian venous drainage into the postpulmonary capillary circulation).

The data show, in addition, that some patients with alveolar-capillary block have more than the normal flow through anatomic shunts (J.W., H.S., O.B., P.S.). In the two subjects who later succumbed to their disease (A.W. and J.B.), there was a marked increase in the flow through shunts. We do not know whether this is due to actual development of pulmonary artery-to-vein shunts or to continued blood flow to regions with no ventilation (obstructed airways).

Of even greater interest is that when 10 of the 11 patients were breathing air their measured arterial $\mathrm{O}_{2}$ saturations agreed well with those calculated on the basis of uneven ventilation to blood flow ratios (Table IV); this indicates that their anoxemia can be explained entirely on the basis of uneven distribution without invoking the factor of impaired diffusion. Late in the disease process, venous admixture became the dominant factor in causing arterial hypoxemia. The singlebreath $\mathrm{O}_{2}$ test (9) was abnormal in 8 of the 11 patients, which suggests uneven distribution of ventilation in time as well as in regions of the lung. This asynchrony of emptying reflects an uneven distribution of alveolar compliances and resistances, undoubtedly related to uneven dis-

TABLE IV

Fractional ventilation and perfusion of well and poorly ventilated regions *

\begin{tabular}{|c|c|c|c|c|c|c|c|c|c|c|c|c|}
\hline \multirow[b]{3}{*}{ Patient } & & & & & \multicolumn{5}{|c|}{ Poorly Ventilated Region } & \multirow[b]{3}{*}{$\begin{array}{l}\mathrm{ScO}_{2-}- \\
\mathrm{SaO}_{2}\end{array}$} & \multirow[b]{3}{*}{$\begin{array}{l}\text { Calc. } \\
\mathrm{SaO}_{2}\end{array}$} & \multirow[b]{3}{*}{$\begin{array}{c}\text { Observed } \\
\mathrm{SaO}_{2}\end{array}$} \\
\hline & \multicolumn{4}{|c|}{ Well ventilated region } & \multirow[b]{2}{*}{$\% \dot{\mathrm{V}}_{\mathrm{A}}$} & \multirow[b]{2}{*}{ \%фं c } & \multirow[b]{2}{*}{$\dot{\mathrm{V}}_{\mathbf{A}} / \dot{\mathrm{Q}}_{\mathbf{c}}$} & \multirow[b]{2}{*}{$\mathrm{ScO}_{2}$} & \multirow{2}{*}{$\begin{array}{c}\text { Calc. } \\
\text { ScO2 } \\
\text { (mixed) }\end{array}$} & & & \\
\hline & $\% \dot{\mathrm{V}}_{\mathrm{A}}$ & $\% \dot{Q}_{\mathbf{c}}$ & $\dot{\mathrm{V}}_{\mathrm{A}} / \dot{\mathrm{Q}}_{\mathrm{c}}$ & $\mathrm{SCO}_{2}$ & & & & & & & & \\
\hline Normal & 0.60 & 0.60 & 1.00 & 97.5 & 0.40 & 0.40 & 1.00 & 97.5 & 97.5 & 0.5 & 97.0 & 97.0 \\
\hline J.W. & 0.54 & 0.15 & 3.00 & 99.0 & 0.46 & 0.85 & 0.50 & 95.0 & 96.0 & 2.5 & 93.5 & 94.0 \\
\hline F.F. & 0.91 & 0.53 & 1.45 & 98.0 & 0.09 & 0.47 & 0.20 & 86.0 & 93.5 & 0.5 & 93.0 & 95.0 \\
\hline E.S. & 0.87 & 0.60 & 1.20 & 98.0 & 0.13 & 0.40 & 0.25 & 88.0 & 92.0 & 1.5 & 90.5 & 91.0 \\
\hline J.R. & 0.73 & 0.70 & 0.85 & 97.5 & 0.27 & 0.30 & 0.75 & 96.5 & 97.0 & 0.5 & 96.5 & 97.0 \\
\hline R.R. & 0.73 & 0.68 & 0.90 & 97.5 & 0.27 & 0.32 & 0.70 & 96.0 & 97.0 & 0.0 & 97.0 & 97.0 \\
\hline B.F. & 0.92 & 0.87 & 0.90 & 97.5 & 0.08 & 0.13 & 0.55 & 95.0 & 96.5 & 1.5 & 95.0 & 93.5 \\
\hline H.S. & 0.73 & 0.25 & 2.45 & 98.5 & 0.27 & 0.75 & 0.30 & 91.0 & 93.5 & 1.5 & 92.0 & 94.0 \\
\hline O.B. & 0.62 & 0.32 & 1.70 & 98.0 & 0.38 & 0.68 & 0.50 & 95.0 & 96.5 & 1.5 & 95.0 & 95.0 \\
\hline P.S. & 0.91 & 0.76 & 1.00 & 97.5 & 0.09 & 0.24 & 0.30 & 91.0 & 95.5 & 1.5 & 94.0 & 91.0 \\
\hline A.W. & 0.85 & 0.28 & 3.00 & 99.0 & 0.20 & 0.72 & 0.27 & 89.0 & 92.5 & 0.5 & 92.0 & 93.0 \\
\hline J.B. & 0.65 & 0.35 & 1.00 & 97.5 & 0.65 & 0.35 & 1.00 & 97.5 & 97.5 & 0.5 & 97.0 & 99.0 \\
\hline
\end{tabular}

* $\dot{\mathrm{V}}_{\mathrm{A}}=$ alveolar ventilation to region; $\dot{\mathrm{Q}}_{\mathrm{c}}=$ pulmonary capillary blood flow to region; $\mathrm{ScO}_{2}=$ saturation of the end-capillary bloor leaving region $\mathrm{ScO}_{2}$ (mixed) =saturation of the mixed end-capillary blood; $\mathrm{ScO}_{2}-\mathrm{SaO}_{2}=$ difference in saturation between mixed end-capillary blood and arterial blood due to anatomical shunts. 
tribution of thickening of alveolar-capillary membranes.

\section{DISCUSSION}

It has recently been pointed out that patients with alveolar-capillary block may have considerable overventilation of some regions of the lung (10) and overperfusion of others (11). Our data suggest that this unequal distribution of ventilation and perfusion and venous admixture account for the hypoxemia of these patients at rest. Because of this, we believe that the usual concept that thickened alveolar-capillary membranes cause arterial hypoxemia at rest because of impairment of $\mathrm{O}_{2}$ diffusion should be modified.

To illustrate this, we have calculated the effect on the $\mathrm{O}_{2}$ diffusing capacity, $\mathrm{DL}_{\mathrm{O}_{2}}$, of increasing the thickness of the alveolar-capillary membranes. We used the equation (12)

$$
\frac{1}{\mathrm{DL}_{\mathrm{O} 2}}=\frac{1}{\mathrm{DM}}+\frac{1}{\theta \mathrm{V}_{\mathrm{e}}}
$$

where $D_{M}$ is the diffusing capacity of the membrane, $\theta$ is the oxyhemoglobin reaction rate constant, and $V_{c}$ is the pulmonary capillary blood volume. This equation allows us to calculate the effect of increasing the thickness of the alveolarcapillary membranes, assuming that the diffusing coefficient of the membranes remains unchanged when their thickness is increased. Normally the resistance to diffusion through the membranes is about equal to the resistance to diffusion offered by the red blood cell. If $\mathrm{DL}_{\mathrm{O}_{2}}$ equals $20 \mathrm{ml}$ per minute per $\mathrm{mm} \mathrm{Hg} \mathrm{Po}_{2}$, and if we assume that the membrane is $1 \mu$ thick, then doubling the thickness would halve DM, according to Fick's first law (12). This would result in decreasing $\mathrm{DL}_{\mathrm{O}_{2}}$ to $13.3 \mathrm{ml}$ per minute per $\mathrm{mm} \mathrm{Hg} \mathrm{Po}_{2}$. If $\theta \mathrm{V}_{\mathrm{c}}$ is decreased correspondingly, $\mathrm{DL}_{\mathrm{O}_{2}}$ would be reduced to $10 \mathrm{ml}$ per minute per $\mathrm{mm} \mathrm{Hg} \mathrm{Po}_{2}$. The effect on $\mathrm{DL}_{\mathrm{O}_{2}}$ of increasing membrane thickness, with $\theta \mathrm{V}_{\mathrm{c}}$ constant, is shown graphically by the hyperbolic curve of Figure 1. These values are deduced from data of the kinetics of the reaction $\mathrm{Hb}+\mathrm{O}_{2} \rightleftharpoons \mathrm{HbO}_{2}$ for human erythrocytes at various levels of $\mathrm{O}_{2}$ saturation when applied to a forward type of Bohr integration (13). The calculations indicate that there is a large safety factor for the diffusion of $\mathrm{O}_{2}$ (14); DM can be reduced to one-sixth to one-eighth of its normal

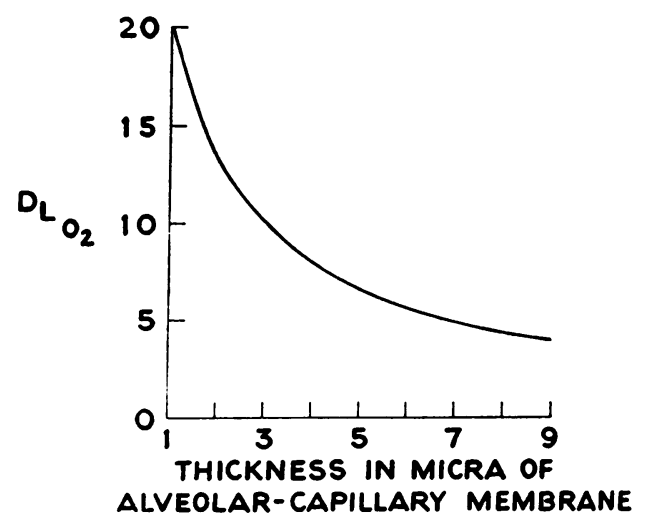

Fig. 1. Graph SHowing Relationship Between DLo: AND thickNess OF ALVEOLAR CAPILlary MEMBRANES.

value before a measurable $(1 \mathrm{~mm} \mathrm{Hg}$ ) (A-a) $\mathrm{PO}_{2}$ difference due to impaired diffusion occurs, all else kept constant.

It is important to consider what increasing the thickness of the membrane to 6 to $8 \mu$ does to the resting volume of alveoli. The normal range of alveolar diameter is 60 to $300 \mu$ (15). The reduction in volume would be approximately 60 per cent for the smaller alveoli and 20 per cent for those in the middle range. If the alveolarcapillary membranes were not thickened uniformly, some of the smaller alveoli could be completely filled, and their capillaries might act as pulmonary artery-to-vein shunts (16).

Uneven thickening of alveolar-capillary membranes would have important effects on the distribution of ventilation. Compliance of fibrotic alveoli would be decreased because of stiffening of their walls and because of their reduced size (17). Both factors would reduce the ventilation to the affected alveoli.

If the perfusion of these affected alveoli was not reduced proportionately, hypoxemia of the arterial blood would occur because of uneven ventilation-perfusion relationships and venous admixture. The data presented here suggest that this is the case.

An analysis of the course of $\mathrm{O}_{2}$ uptake in the pulmonary capillaries by the method of Staub, Bishop and Forster (13), which is based on single-breath Pco data and the reaction kinetics of $\mathrm{O}_{2}$ and red blood cells, agrees with the present conclusion. They calculated that, under a wide variety of conditions in healthy subjects and in 
patients with impaired diffusion, no significant desaturation (alveolar to end-capillary $\mathrm{Po}_{2}$ difference), due to diffusion, results.

\section{SUMMARY}

1. Hypoxemia in 11 patients with a clinical diagnosis of alveolar-capillary block syndrome could be explained on the basis of uneven distribution of ventilation in relation to blood flow and pulmonary artery-to-vein shunting; the latter factor became more important late in the course of the illness.

2. Uneven changes in compliance of alveoli could account for the uneven ventilation.

3. The increase in pulmonary artery-to-vein shunting could result from the complete filling of some air spaces with the thickened alveolar capillary membranes.

\section{REFERENCES}

1. Austrian, R., McClement, J. H., Renzetti, A. D., Jr., Donald, K. W., Riley, R. L., and Cournand, A. Clinical and physiologic features of some types of pulmonary disease with impairment of alveolarcapillary diffusion. The syndrome of "alveolarcapillary block." Amer. J. Med. 1951, 11, 667.

2. Donald, K. W., Renzetti, A., Riley, R. L., and Cournand, A. Analysis of factors affecting concentrations of oxygen and carbon dioxide in gas and blood of lungs: Results. J. appl. Physiol. 1952, 4, 497.

3. Bartels, H., and Rodewald, G. Die alveolär-arterielle Sauerstoffdruckdifferenz und das Problem des Gasaustausches in der menschlichen Lunge. Pflüg. Arch. ges. Physiol. 1953, 258, 163.

4. Berggren, S. M. The oxygen deficit of arterial blood caused by non-ventilating parts of the lung. Acta physiol. scand. 1942, 4, suppl. 11.

5. Cournand, A., Baldwin, E. DeF., Darling, R. C., and Richards, D. W., Jr. Studies on intrapulmonary mixture of gases. IV. The significance of the pulmonary emptying rate and a simplified open circuit measurement of residual air. J. clin. Invest. 1941, 20, 681.

6. Ogilvie, C. M., Forster, R. E., Blakemore, W. S., and Morton, J. W. A standardized breath holding technique for the clinical measurement of the diffusing capacity of the lung for carbon monoxide. J. clin. Invest. 1957, 36, 1 .

7. Finley, T. N. The determination of uneven pulmonary blood flow from the arterial oxygen tension during nitrogen washout. J. clin. Invest. 1961, 40, 1727.

8. Briscoe, W. A. A method for dealing with data concerning uneven ventilation of the lung and its effect on blood gas transfer. J. appl. Physiol. 1959, 14, 291.

9. Comroe, J. H., Jr., and Fowler, W. S. Lung function studies. VI. Detection of uneven alveolar ventilation during a single breath of oxygen. Amer. J. Med. 1951, 10, 408.

10. Holland, R. A. B. Physiologic dead space in the Hamman-Rich syndrome. Physiologic and clinical applications. Amer. J. Med. 1960, 28, 61.

11. Read, J., and Williams, R. S. Pulmonary ventilation. Blood flow relationships in interstitial disease of the lungs. Amer. J. Med. 1959, 27, 545.

12. Forster, R. E. Exchange of gases between alveolar air and pulmonary capillary blood: Pulmonary diffusing capacity. Physiol. Rev. 1957, 37, 391.

13. Staub, N. C., Bishop, J. M., and Forster, R. E. Velocity of $\mathrm{O}_{2}$ uptake by human red blood cells. J. appl. Physiol. 1961, 16, 511.

14. Staub, N. C. Is there ever a measurable alveolararterial $\mathrm{O}_{2}$ gradient due to diffusion? (abstract). Physiologist 1961, 4, no. 3, 115 .

15. Macklin, C. C., and Hartroft, W. S. Report to the Sub-committee on Physiological Aspects of Chemical Warfare. Ottawa, Canadian Defense Research Board, 1943.

16. Said, S. I., Thompson, W. T., Jr., Patterson, J. L., Jr., and Brummer, D. L. Shunting effect of extreme impairment of pulmonary diffusion. Bull. Johns Hopk. Hosp. 1960, 107, 255.

17. Clements, J. A., Brown, E. S., and Johnson, R. P. Pulmonary surface tension and the mucus lining of the lungs: Some theoretical considerations. J. appl. Physiol. 1958, 12, 262. 